\title{
TANGGUNG JAWAB NOTARIS TERHADAP AKTA YANG CACAT SECARA FORMAL
}

\author{
Adam Pramana Putra \\ Magister Kenotariatan, Fakultas Hukum, Universitas Narotama Surabaya \\ Email: adampramanaputra@gmail.com
}

\begin{abstract}
ABSTRAK
Akta Otentik adalah akta yang kebenaran Formal dan Materiil serta unsur-nsur Subyektif dan Unsur Obyektif harus sesuai dengan Peraturan Perundang-Undangan yang berlaku. Penelitian ini menganalisis bentuk pertanggungjawaban notaris sebagai pejabat pembuat akta terhadap akta yang mengandung cacat secara formal dan akibat hukum terhadap akta otentik jika saksi-saksi dalam akta tidak hadir pada saat akta dibacakan. Metode penelitian yang digunakan adalah penelitian hukum normatif, yaitu penelitian hukum yang dilakukan dengan cara meneliti bahan pustaka atau bahan hukum sekunder sedangkan pendekatan masalah dilakukan dengan menggunakan pendekatan undang-undang dan pendekatan konseptual. Hasil penelitian menunjukkan bahwa Akta Notaris yang tidak memenuhi syarat Formal dan Materiil serta tidak memenuhi Unsur Subjektif dan Unsur Objektif, maka akta tersebut dapat menjadi batal demi hukum, dan/atau dapat dibatalkan. Ketidakhadiran saksi-saksi pada saat pembacaan dan penandatanganan minuta akta dapat membuat notaris dinyatakan memberikan keterangan palsu dalam akta otentik.
\end{abstract}

Kata Kunci: Akta Otentik, Tanggung jawab Notaris, Kebenaran Formal, Kebenaran Materil

\begin{abstract}
Authentic Deed is a deed in which the truth of the Formal and Material and Subjective elements and the Objective Elements must be in accordance with the applicable Laws and Regulations. This study analyzed the form of notary's responsibility as an official making deeds on deeds that formally defects and legal consequences for authentic deeds if the witnesses in the deed are not present at the time the deed is read. The research method used normative legal research, namely legal research conducted by examining library materials or secondary legal material while the problem approach is carried out using a legal approach and conceptual approach. The results of the study indicate that the Notary Deed that does not meet the Formal and Maternal requirements and does not meet the Subjective Elements and Objective Elements, then the deed can be null and void, and / or can be canceled. The absence of witnesses at the time of reading and signing the Minuta deed can make the notary be declared to give false information in an authentic deed.
\end{abstract}

Key words: Authentic Deed, Notary Responsibility, Formal Truth, Material Truth 


\section{PENDAHULUAN}

Masyarakat di era globalisasi ini telah mengalami perkembangan yang cukup pesat, dengan perkembangan yang semakin pesat tersebut, kebutuhan masyarakat atas jasa notaris semakin dibutuhkan. Hal ini terutama terkait dari perbuatannya dengan adanya keinginan dari masyarakat untuk menyatakan kehendak, alat bukti yang otentik dengan salah satunya adalah digunakan untuk alat bukti dalam suatu perkara di Pengadilan.

Pejabat Umum adalah organ negara yang diperlengkapi dengan kekuasaan umum, berwenang menjalankan sebagian dari kekuasaan umum, berwenang menjalankan sebagian dari kekuasaan negara untuk membuat alat bukti tertulis dan otentik dalam bidang hukum perdata ${ }^{1}$. Pasal 1 angka 1 Undang-Undang Nomor 30 Tahun 2004 Tentang Jabatan Notaris sebagaimana telah diubah dengan Undang-Undang Nomor 2 Tahun 2014 Tentang Perubahan Atas Undang-Undang Nomor 30 Tahun 2004 Tentang Jabatan Notaris (UUJN) menyatakan : "Notaris adalah pejabat umum yang berwenang untuk membuat akta otentik dan kewenangan lainnya sebagaimana dimaksud dalam Undang-Undang ini “.

Akta notaris harus mengandung syarat-syarat yang diperlukan agar tercapai sifat otentik dari akta itu misalnya mencantumkan identitas para pihak, membuat isi perjanjian yang dikehendaki para pihak, menandatangani akta, dan sebagainya. Apabila syarat-syarat itu tidak terpenuhi maka akta tersebut dapat dibatalkan (vernitigbaar) atau batal demi hukum ( venrechtswege nietig ). Tidak menyalahi pasal 1869 KUHPerdata dan 1320 KUHPerdata (pada prinsipnya obyek dan subyek perjanjian). ${ }^{2}$

Berdasarkan Pasal 16 ayat (1) huruf 1 UUJN, Notaris wajib membacakan akta dihadapan penghadap dengan dihadiri oleh paling sedikit dua orang saksi dan ditandatangani pada saat itu juga oleh penghadap, saksi-saksi dan notaris. Tujuan pembacaan akta ini adalah agar para pihak saling mengetahui isi dari akta tersebut sebab

\footnotetext{
${ }^{1}$ Wawan Setiawan, "Kedudukan dan Keberadaan Pejabat Umum serta PPAT dibandingkan dengan kedudukan Pejabat Tata Usaha Negara Menurut Sitem Hukum Nasional", Makalah, disampaikan dalam acara Upgrading Pengurus Pusat Pejabat Pembuat Akta Tanah, Jakarta, 2 Juli 2001, hal. 8

${ }^{2}$ Herlien Budiono, Kumpulan Tulisan Hukum Perdata Di Bidang Kenotariatan, Citra Aditya Bakti, Bandung, 2008 hal.281.
} 
isi dari akta itu merupakan kehendak para pihak. Pembacaan akta ini juga dilakukan agar pihak yang satu tidak merasa dirugikan apabila terdapat keterangan atau redaksi akta yang memberatkan atau merugikan terhadap pihak yang lain. Dalam prakteknya sering terjadi notaris dilibatkan jika terjadi perkara antara para pihak, padahal sengketa yang terjadi bukanlah antara para pihak dengan notaris mengingat notaris bukan pihak dalam akta yang dibuatnya, namun notaris sering harus keluar masuk gedung pengadilan untuk mempertanggung jawabkan aktanya meskipun hanya terkadang sebagai saksi.

Notaris sebagai pejabat umum kepadanya dituntut tanggung jawab terhadap akta yang dibuatnya. Apabila akta yang dibuat ternyata dibelakang hari mengandung sengketa misalnya dengan memuat keterangan palsu, maka hal ini perlu dipertanyakan, apakah akta ini merupakan kesalahan notaris atau kesalahan para pihak yang tidak memberikan data (keterangan dan dokumen) yang sebenarnya dan para pihak memberikan keterangan yang tidak benar ataukah adanya kesepakatan yang dibuat antara notaris dengan salah satu pihak yang menghadap. Apabila akta yang dibuat/diterbitkan notaris mengandung cacat hukum karena kesalahan notaris baik karena kelalaian maupun karena kesengajaan notaris itu sendiri maka notaris itu harus memberikan pertanggungjawaban secara moral dan secara hukum.

\section{RUMUSAN MASALAH}

1) Apa pertanggungjawaban notaris sebagai pejabat pembuat akta terhadap akta yang mengandung cacat secara formal ?

2) Apa akibat hukum terhadap akta otentik jika saksi - saksi dalam akta tidak hadir pada saat akta dibacakan?

\section{METODE PENELITIAN}

Penelitian ini menggunakan metode penelitian hukum normatif yang dilakukan untuk mencari pemecahan masalah atas permasalahan hukum yang ada. Pendekatan penelitian yang digunakan adalah pendekatan undang-undang (statute approach) dan pendekatan konseptual (conceptual approach). 


\section{PEMBAHASAN}

\section{Pertanggungjawaban Notaris Sebagai Pejabat Pembuat Akta Terhadap Akta Yang Mengandung Cacat Secara Formal}

Sebagai pejabat umum yang berwenang membuat akta otentik mengenai semua perbuatan, perjanjian, dan ketetapan yang diharuskan oleh peraturan perundang undangan atau yang dikehendaki oleh yang berkepentingan untuk dinyatakan dalam akta otentik, serta kewenangan lain sabagaimana yang dimaksud dalam UUJN semuanya sepanjang tidak juga ditugaskan atau dikecualikan kepada pejabat lain atau orang lain yang ditetapkan oleh undang-undang (Pasal 1 angka 1 Jo. Pasal 15 UUJN) dapat kita pahami bahwa Jabatan Notaris merupakan suatu jabatan yang penting, luhur dan terhormat, sehingga sudah selayaknya dan bahkan merupakan keharusan diatur dalam suatu undang-undang. ${ }^{3}$

Notaris dalam menjalankan jabatannya, harus berpegang teguh pada 2 (dua) parameter yang diatur dalam UUJN, yaitu : pertama, Notaris mempunyai kewenangan untuk melakukan penyuluhan hukum berkaitan dengan akta yang dibuatnya ( Pasal 15 ayat 2 UUJN ). Peran notaris dalam membuat akta otentik bukanlah sekedar juru tulis atau notulis, yang fungsinya hanya mendengar keterangan penghadap yang disampaikan kepada Notaris, kemudian menuangkan mentah-mentah keterangan itu dalam akta, membacakan akta dan menandatangani akta. Sebagai Pejabat Umum yang mengemban Kepercayaan Negara dan Masyarakat, Notaris wajib memberikan Penyuluhan Hukum, agar keterangan yang diberikan itu sesuai dengan aturan hukum; Kedua, Notaris wajib menolak membuat akta jika keterangan dan atau data-data formal yang disampaikan bertentangan dengan aturan hukum ( Pasal 16 ayat 1 huruf d UUJN ).

Kewenangan notaris diberikan oleh Undang-undang Jabatan Notaris, berkaitan dengan kebenaran materiil atas akta otentiknya, jika dilakukan tanpa kehati-hatian sehingga membahayakan masyarakat dan atau menimbulkan kerugian baik yang dilakukan dengan sengaja maupun tidak dan perbuatan tersebut diancam dan atau memenuhi unsur-unsur tindak pidana, maka notaris harus mempertanggung jawabkan perbuatan tersebut secara pidana.

${ }^{3}$ Habib Adjie, Hukum Notaris Indonesia, Tafsir Tematik Terhadap UU No.30 Tahun 2004 Tentang Jabatan Notaris, Refika Aditama, Bandung, 2008, hal 23 
Bahwa dalam akta Notaris dapat batal demi hukum adalah jika syarat Subyektif dan obyektif nya tidak terpenuhi. Ketentuan Pasal 1333 KUHPerdata menentukan : "Suatu perjanjian harus mempunyai sebagai pokok suatu barang yang paling sedikit ditentukan jenisnya yang di kemudian hari jumlah (barang) tersebut dapat ditentukan atau dihitung". Selanjutnya ditegaskan dalam Pasal 1335 KUHPerdata : "Suatu perjanjian tanpa sebab atau yang telah dibuat karena sesuatu sebab yang palsu atau terlarang, maka perjanjian tersebut tidak mempunyai kekuatan, ini membuktikan bahwa setiap perjanjian harus mempunyai kausa yang halal“. Lebih lanjut menurut Pasal 1336 KUHPerdata: "Jika tidak dinyatakan sesuatu sebab, tetapi ada sesuatu sebab yang halal ataupun jika ada sesuatu sebab lain daripada yang dinyatakan persetujuannya namun demikian adalah sah."

Suatu sebab adalah terlarang, apabila dilarang oleh undang-undang, atau apabila berlawanan dengan kesusilaan atau ketertiban umum. Sehingga dengan demikian suatu perjanjian batal demi hukum, jika :

1. Tidak mempunyai objek tertentu yang dapat ditentukan.

2. Mempunyai sebab yang dilarang oleh undang-undang atau berlawanan dengan kesusilaan atau ketertiban umum.

Jabatan Notaris merupakan jabatan yang terhormat yaitu suatu jabatan yang dalam pelaksanaannya mempertaruhkan jabatannya dengan mematuhi dan tunduk pada UUJN dan Kode Etik Notaris. Dengan demikian diharapkan agar notaris dalam menjalankan jabatannya mempunyai integritas moral dengan memperhatikan nilai agama, sosial dan budaya yang berlaku dalam masyarakat. Oleh karena itu seorang notaris tidak mungkin menerbitkan suatu akta yang mengandung cacat hukum dengan cara sengaja, akan tetapi tidak menutup kemungkinan bahwa diluar sepengetahuan notaris para pihak/penghadap yang meminta untuk dibuatkan akta memberikan keterangan-keterangan yang tidak benar dan menyerahkan surat-surat/dokumendokumen yang tidak benar sehingga setelah semuanya dituang kedalam akta lahirlah sebuah akta yang mengandung keterangan palsu yang disampaikan oleh penghadap. ${ }^{4}$

\footnotetext{
${ }^{4}$ G.H.S. Lumban Tobing,, Peraturan Jabatan Notaris, Erlangga, Jakarta, 1996, hal.3.
} 
Bila seorang notaris dapat dibuktikan ikut sebagai "dader Intelektual" atau "Ide Guide” dapat diancam pidana pasal 55 Kitab Undang-Undang Hukum Pidana ( KUHP ) yang menyatakan :

Dipidana sebagai si Pembuat sesuatu tindak pidana ;

$\mathrm{Ke}-1$, orang melakukan yang menyuruh melakukan atau yang turut melakukan perbuatan itu ;

Ke - 2, orang yang dengan pemberian upah, perjanjian, salah memakai kekuasaan atau martabat, memakai paksaan, ancaman atau tipu karena memberi kesempatan, ikhtiar atau keterangan, dengan sengaja menghasut supaya perbuatan tersebut.

Dalam hal tersebut, menentukan bahwa tindak pidana menyuruh mencantumkan suatu keterangan palsu didalam suatu akta otentik merupakan suatu tindak pidana pemalsuan. Dengan terjadinya kasus semacam ini maka akan menyebabkan notaris harus mempertanggungjawabkan akta yang telah dibuatnya, mengingat notaris merupakan pejabat umum yang berwenang membuat akta otentik dan akta otentik yang dibuatnya setelah ditandatangani oleh para pihak menjadi dokumen negara. Sehubungan dengan hal tersebut diatas notaris dalam mempertanggungjawab kan akta yang telah diterbitkannya untuk dapat diperiksa atau diproses oleh aparat hukum.

Adanya kewenangan notaris yang diberikan oleh undang-undang Jabatan Notaris, berkaitan dengan kebenaran materiil atas akta otentiknya, jika dilakukan tanpa kehati-hatian sehingga membahayakan masyarakat dan atau menimbulkan kerugian baik yang dilakukan dengan sengaja maupun tidak dan perbuatan tersebut diancam dan atau memenuhi unsur-unsur tindak pidana, maka notaris harus mempertanggung jawabkan perbuatan tersebut secara perdata maupun pidana.

Sejak kehadiran penghadap di hadapan notaris untuk menuangkan tindakan atau perbuatannya dalam bentuk akta otentik, kemudian notaris membuat akta otentik tersebut sesuai keinginan para penghadap dengan memperhatikan syarat dan ketentuan yang ditetapkan oleh UUJN, maka sejak penandatanganan akta tersebut oleh para pihak, saksi-saksi dan notaris, lahirlah hubungan hukum antara notaris dengan para penghadap.

Hubungan hukum tersebut yaitu adanya kepercayaan para pihak atau penghadap kepada notaris dalam menuangkan keinginannya pada suatu akta otentik, karena para pihak ingin dengan akta otentik yang dibuat oleh notaris tersebut akan menjamin bahwa 
akta yang dibuat tersebut sesuai dengan aturan hukum yang sudah ditentukan, sehingga kepentingan para pihak terlindungi dengan adanya akta tersebut.

Dengan kata lain bahwa akta otentik menjamin adanya kepastian hukum. Dengan demikian dapat dihindari kerugian maupun sengketa yang terjadi dikemudian hari karena adanya pihak-pihak yang memberikan keterangan palsu. Dengan hubungan hukum seperti itu, maka perlu para penghadap, karena pada saat pertemuan tersebut belum terjadi permasalahan ditentukan kedudukan hubungan hukum tersebut yang merupakan awal dari tanggunggugat Notaris. Pada dasarnya hubungan hukum antara notaris dengan para pihak yang telah membuat akta otentik di hadapan notaris tidak dapat dikonstruksikan / ditentukan pada awal pertemuan atau hubungan antara notaris dengan para penghadap, karena pada saat pertemuan tersebut belum terjadi permasalahan. Dalam hal ini tidak hanya akta otentik yang kekuatan hukumnya mengalami penurunan menjadi akta yang berkekuatan sebagai tulisan hukum atau akta dibawah tangan, namun tentunya harus ada ganti rugi yang harus ditanggung oleh Notaris.

\section{Akibat Hukum Terhadap Akta Otentik Notariil Jika Saksi - Saksi Dalam Akta} Tidak Hadir Pada Saat Akta Dibacakan

Akta otentik sebagai akta yang dibuat oleh notaris secara teoritis adalah surat atau akta yang sejak semula dengan sengaja secara resmi dibuat untuk pembuktian. Sejak semula dengan sengaja berarti bahwa sejak awal dibuatnya surat ini tujuannya adalah untuk pembuktian di kemudian hari jika terjadi sengketa, sebab surat yang tidak dengan sengaja dibuat sejak awal sebagai alat bukti seperti surat korespondensi biasa. Dikatakan dengan resmi karena tidak dibuat di bawah tangan. Sedangkan secara dogmatis yakni menurut Pasal 1868 KUHPerdata, suatu akta otentik adalah akta yang bentuknya ditentukan oleh undang-undang (welke in de wettelijke vorm is verleden) dan dibuat oleh atau dihadapan pegawai-pegawai (pejabat) umum ( door of ten overstaan van openbaare ambtenaren) yang berkuasa untuk itu (daartoe bevoegd) ditempat akta tersebut dibuatnya. ${ }^{5}$

\footnotetext{
${ }^{5}$ Habib Adjie, Op.Cit., hal. 38
} 
Berdasarkan Pasal 1868 KUHPerdata, akta otentik dibagi 2 (dua) yaitu :

1. Akta otentik yang dibuat oleh pejabat yang berwenang dan;

2. Akta otentik yang dibuat dihadapan pejabat yang berwenang. ${ }^{6}$

Akta otentik yang dibuat oleh pejabat yang bewenang pada dasarnya dapat diidentifikasi dari dua ciri khas yaitu :

1. Inisiatif datang dari orang kepada siapa akta itu diberikan, seperti panggilan atau berita acara ;

2. Meskipun demikian dalam hal tertentu dimungkinkan adanya permohonan dari orang yang bersangkutan. Demikian halnya juga yang terjadi pada pejabat Notaris dalah hal tertentu dapat juga bertindak membuat akta yang dibuat olehnya sebagai pejabat yang berwenang. Misalnya berita acara rapat umum pemegang saham (RUPS) perseroan. Dalam kasus ini notaris hanya berfungsi membuat laporan tentang hal yang terjadi, dibicarakan dan diputuskan dalam RUPS tersebut. Notaris hanya mengkonstantir atau menentukan segala tingkah laku para peserta RUPS yang hadir.

Sementara akta yang dibuat dihadapan pejabat yang berwenang seperti notaris terdapat ciri pokok yang mesti dipenuhi agar, agar pembuatan itu memenuhi syarat akta otentik yaitu :

1. Pada umunya bersifat partij, artinya yang datang dihadapan notaris paling tidak terdiri dari dua pihak. Ada penjual dan ada pembeli. Yang satu pihak kreditur yang satu lagi pihak debitur. Oeh karena pihak bersifat partij maka akta otentik yang dibuat oleh notaris tersebut disebut sebagai akta para pihak, sedangkan isinya disebut persetujuan para pihak ;

2. Inisiatif datang dari para pihak, para pihak atas kemauan sendiri datang ke kantor notaris. Dihadapan notaris kedua belah pihak atau para pihak dapat memberi atau menyampaikan keterangan sendiri, dan keterangan yang disampaikan dapat berbentuk lisan (oral) atau tulisan (in writing). Para pihak meminta kepada notaris, agar keterangan yang mereka sampaikan dituangkan dalam bentuk akta ;

${ }^{6}$ Hatta Isnaini Wahyu Utomo, "Pelaksanaan Tugas Jabatan Notaris : Bahan Diskusi Dalam Persiapan Menghadapi Ujian Kode Etik Notaris", disampaikan pada acara Belajar Bareng Alumni, Univeritas Narotama, 12 Februari 2017, hal. 14 
3. Notaris bersifat pasif: pada prinsipnya notaris bersifat pasif melayani para pihak yang menghadap kepadanya. Dia hanya bertugas mencatat atau menuliskan dalam akta apa-apa yang diterangkan para pihak. Tidak berhak mengubah, mengurangi atau menambah apa yang diterangkan para penghadap. ${ }^{7}$

Saksi Akta Notaris merupakan para saksi yang ikut serta di dalam pembuatan terjadinya akta(instrumen), maka dari itulah disebut Saksi Instrumentair (Instrumentaire Getuigen).

Bahwa salah satu syarat formal akta Notaris sebagaimana tersebut dalam Pasal 38 UUJN dan mengenai saksi ( Instrumentair ) ini ditegaskan dalam Pasal 38 ayat (4) huruf c UUJN bahwa pada akhir atau penutup akta harus memuat nama lengkap, tempat dan tanggal lahir, pekerjaan, jabatan, kedudukan, dan tempat tinggal dari tiap-tiap saksi. Secara keseluruhan akta Notaris, akan disebut akta Notaris lengkap jika semua syarat formal tersebut dipenuhi sehingga mempunyai kekuatan pembuktian yang sempurna, sehingga kedudukan saksi akta yang merupakan salah satu syarat formal sudah dipertanggungjawabkan secara hukum.

Pada dasarnya, akta mempunyai dua fungsi yaitu fungsi formal ( formalitas causa) dan fungsi alat bukti ( probations causa). Formalitas causa artinya berfungsi untuk lengkapnya atau sempurnanya suatu perbuatan hukum, jadi bukan hanya sahnya perbuatan hukum. Jadi adanya akta merupakan syarat formal untuk adanya suatu perbuatan hukum. Probationis causa berarti akta mempunyai fungsi sebagai alat bukti, karena sejak awal akta tersebut dibuat dengan sengaja untuk pembuktian dikemudian hari. Sifat tertulisnya suatu perjanjian dalam bentuk akta ini tidak membuat sahnya perjanjian tetapi hanyalah agar dapat digunakan sebagai alat bukti dikemudian hari. ${ }^{8}$

Akta otentik mempunyai kekuatan bukti formal dan materil. Formal yaitu bahwa benar para pihak sudah menerangkan apa yang ditulis dalam akta itu. Materiilnya, bahwa apa yang diterangkan tadi adalah benar. Penurunan status kekuatan alat bukti akta Notaris, dapat terjadi jika dalam pembuatan akta tersebut ada hal-hal yang sifatnya wajib dilakukan Notaris, ternyata dalam proses pembuatan aktanya disimpangi oleh

${ }^{7}$ A.A. Andi Prajitno, Pengetahuan Praktis Tentang Apa dan Siapa Notaris di Indonesia?Sesuai UUJN Nomor 2 Tahun 2014, Perwira Media Nusantara, Surabaya, 2015, hal.54

${ }^{8}$ Herlien Budiono, Op.Cit., hal. 34 
Notaris, dan melanggar persyaratan ketentuan yang berlaku dalam suatu aturan dan atau suatu Undang-Undang, banyak pelanggaran-pelanggaran yang dilakukan oleh Notaris dalam proses pembuatan aktanya, pelanggaran dapat terjadi dalam hal Notaris pada saat membuat akta tidak menjamin kebenaran formal atas akta yang dibuatnya tersebut, yang dapat dikatakan terjadi pelanggaran prosedural dalam pembuatan akta, salah satu nya adalah tidak hadirnya saksi-saksi dalam pembacaan dan penandatanganan akta.

Pada pasal 16 ayat 1 Huruf I, ditentukan bahwa : "Dalam menjalankan jabatannya Notaris berkewajiban membacakan akta dihadapan penghadap dengan dihadiri oleh paling sedikit dua orang saksi dan ditandatangani pada saat itu juga oleh penghadap, saksi dan Notaris “. Dalam penjelasan ketentuan Pasal 16 Ayat (1) Huruf 1, UUJN berbunyi, sebagai berikut : "Notaris harus hadir secara fisik dan menandatangani akta dihadapan penghadap dan saksi ". Mengenai ketentuan tersebut terdapat pengecualian sebagaimana disebutkan dalam Pasal 16 ayat (3) angka 7 UUJN yang mengatur sebagai berikut :

"Pembacaan akta sebagaimana dimaksud pada ayat (1) huruf 1 tidak wajib dilakukan, jika penghadap menghendaki agar akta tidak dibacakan karena penghadap telah membaca sendiri, mengetahui, dan memahami isinya, dengan ketentuan bahwa hal tersebut dinyatakan dalam penutup akta serta pada setiap halaman Minuta Akta diparaf oleh penghadap, saksi, dan Notaris"

Apabila syarat formal dalam pembuatan akta tidak terpenuhi maka, akta yang dibuat Notaris tersebut hanya mempunyai kekuatan pembuktian sebagai akta dibawah tangan, selain itu terhadap akta dapat dimintakan pembatalan oleh para pihak yang dirugikan kepada Pengadilan dengan alasan tidak terpenuhinya syarat formal pembuatan akta sebagaimana telah diatur dalam Peraturan Perundang-undangan yang berlaku.

\section{PENUTUP}

\section{Kesimpulan}

Akta Notaris yang tidak memenuhi syarat Formal dan Materiil serta tidak memenuhi Unsur Subjektif dan Unsur Objektif, maka akta tersebut dapat menjadi batal demi hukum, dan / atau dapat dibatalkan, apabila ada upaya untuk membatalkan akta tersebut melalui proses peradilan atau litigasi perdata di pengadilan dan dapat dibuktikan adanya unsur pelnggaran pidana maka Notaris harus bertanggung jawab 
dengan dijatuhi hukuman pidana dan bilamana dalam hal keperdataan Notaris terbukti bersalah karena kekhilafan/kesesatan (dwaling) dan paksaan (dwang), maka Notaris tersebut wajib memberikan ganti rugi, kepada pihak yang menderita kerugian. Ketidakhadiran saksi-saksi pada saat pembacaan dan penandatanganan minuta akta notaris dapat dikatakan memberikan keterangan palsu, sesuai yang diatur dalam pasal 266 KUHP.

\section{Saran}

Perlu adanya pengawasan yang lebih ketat terhadap pelaksanaan jabatan Notaris serta pemberian sanksi yang nyata agar pelanggaran-pelanggaran seperti tidak hadirnya saksi dalam pembuatan akta tidak terus menerus terjadi.

\section{DAFTAR PUSTAKA}

A.A. Andi Prajitno, Pengetahuan Praktis Tentang Apa dan Siapa Notaris di Indonesia?Sesuai UUJN Nomor 2 Tahun 2014, Perwira Media Nusantara, Surabaya, 2015

G.H.S. Lumban Tobing, Peraturan Jabatan Notaris, Erlangga, Jakarta, 1996

Habib Adjie, Hukum Notaris Indonesia, Tafsir Tematik Terhadap UU No.30 Tahun 2004 Tentang Jabatan Notaris, Refika Aditama, Bandung, 2008

Hatta Isnaini Wahyu Utomo, "Pelaksanaan Tugas Jabatan Notaris : Bahan Diskusi Dalam Persiapan Menghadapi Ujian Kode Etik Notaris", disampaikan pada acara Belajar Bareng Alumni, Univeritas Narotama, 12 Februari 2017

Herlien Budiono, Kumpulan Tulisan Hukum Perdata Di Bidang Kenotariatan, Citra Aditya Bakti, Bandung, 2008

Wawan Setiawan, "Kedudukan dan Keberadaan Pejabat Umum serta PPAT dibandingkan dengan kedudukan Pejabat Tata Usaha Negara Menurut Sitem Hukum Nasional", Makalah, disampaikan dalam acara Upgrading Pengurus Pusat Pejabat Pembuat Akta Tanah, Jakarta, 2 Juli 2001 